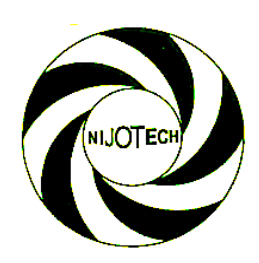

Nigerian Journal of Technology (NIJOTECH)

Vol. 37, No. 2, April 2018, pp. 543 - 547

Copyright@ Faculty of Engineering, University of Nigeria, Nsukka,

Print ISSN: 0331-8443, Electronic ISSN: 2467-8821

http://dx.doi.org/10.4314/njt.v37i2.34

\title{
A CENTURIAL ANALYSIS OF RAINFALL VARIABILITY IN NIGERIA
}

\author{
R. A. Adenodi* \\ Physics Department, AdEyemi College of EducAtion, Ondo, Ondo State, NiGERIA \\ E-mail address: adenodiraph@gmail.com
}

\begin{abstract}
This paper examines rainfall variability in Nigeria using monthly rainfall data from 1901 to 2012. This is necessary for planning and management of agriculture and water resource systems. Data for the study were retrieved from the portal archives of World Bank Climate Change Knowledge. Descriptive statistics, trend analysis, and seasonality index were employed in the study. Fluctuations across the months and years were respectively examined through MAKESENS@ statistics and Seasonality Index. The result revealed minimum and maximum amounts of rainfall in January and August respectively. The $Z$ and $Q$ statistics indicate an upward trend and positive slope respectively but the null hypothesis of no trend is accepted only in November, December and January due to very low amount of rainfall. The highest maximum and minimum amount of rainfall occurred in July and August while the lowest maximum and minimum both took place in January but the years in which these sets of maximums and minimums happened each followed a zigzag pattern which connotes fluctuations in the amount of rainfall. The maximum, minimum and average seasonality indexes are $0.924,0.706$ and 0.779 respectively, which indicate seasonal and markedly seasonal with a long dry season. There is the need to harvest, store and treat excess water during the wet months for use in dry months. The study recommends that the ministry of water resources should adopt best practices to provide water for Nigerians during the long dry months.
\end{abstract}

Key words: Rainfall, climate variability, seasonality index, trend, water resources.

\section{INTRODUCTION}

Rainfall is one of the major climatic resources of Nigeria and can be use as an index of climatic change. Crops, animals and humans derived their water resources mainly from it. It also determines the time in which some crop types can be cultivated and the appropriate farming system for optimum yields $[1,2]$. Every rainy season in Nigeria is associated with tropical storms which claim lives and properties worth millions of naira across the nation [3].These make the study of rainfall variability important for planning and management of agriculture and water resource systems, flood frequency analysis and associated hazard mapping, climate change and its impacts, and other environmental assessments $[4,5,6]$. Flooding is usually caused by heavy rainfall and thunderstorms over a short period, prolonged rainfall or excessive downpour while its deficit results in drought of varying magnitudes [2, 7]. Disasters associated with rainfall include loss of lives and properties worth millions of dollars and traffic obstruction [3]. It is the duty of Nigerian Meteorological Agency (NIMET) to alert Nigerians anytime rainfall would be above normal [8].
Normal rainfall results in adequate supply of water without disaster. Long period of dryness is usually associated with epidemics, such as outbreak of malaria [3] and food shortage apart from shortage of water supply. For some decades, the commonest natural disaster in Nigeria is flooding.

Climate is the average weather or the statistical description in terms of the mean and variability of relevant quantities over a period of time ranging from months to thousands or millions of years [9] and these variations result in drier or wetter, warmer or colder, quiescent or stormy conditions[10]. Climatic parameters such as rainfall, temperature, relative humidity, sunshine hour etc. vary with time and space [11]. Therefore climate variability is the fluctuation in the statistics such as mean, standard deviations (SD) [2], the occurrence of extremes, etc. of the climate on temporal and spatial scales. These changes may be due to natural internal processes or external forcing, or to persistent anthropogenic changes in the composition of the atmosphere or in land use $[9,12,13]$.

Rainfall is a significant climatic variable underlies droughts and floods $[5,14]$. Drought is a period of

*Author tel: $+234-803-442-5682$ 
unusually persistent dry weather that causes damage to crop and reduce water supply. The meteorologists view it as departure of precipitation from normal, the hydrologists considered it as a condition in which the surface and subsurface water supplies are below normal while the socio-economists refers to it as a situation in which physical water shortages begin to affect people [15]. Basically, it is a shortage of water that has adverse effect on plants, animals and humans. The temporal and spatial variability of rainfall is useful in evaluating change in climate, water scarcity, epidemic, flooding and associated hazards, hurricanes, plant wilting and environmental disasters [4]. The heavy reliance on rain-fed agriculture as witnessed in Nigeria has resulted in many livelihoods being highly susceptible to rainfall variability [16 - 18]. Devastating social and economic impacts occur when rainfall characteristics such as amount, intensity, frequency and timing differ from normal conditions. This underscores the need for this study.

The nexus between large scale water storage, food and energy productions will be of socio-economic benefits to a nation like Nigeria bedeviled with electrical power outage which has affected the economy negatively. Water stored in dams can be used for irrigated agriculture [19] as well as hydropower generation. Irrigated agriculture land will foster greater food security and electricity generated from hydropower will contribute to large scale grid-based electrification which will in turn boost industrial outputs, economic growth and human development [20].

\section{MATERIAL AND METHODS}

The data for this study was retrieved from the online archives of World Bank Climate Change Knowledge (sdwebx.worldbank.org). Descriptive statistics, trend analysis and seasonality index (SI) were used in this analysis. SI quantified the variability through the year while Mann-Kendall and Sen's tests were used to assess the fluctuations through the month.

Mann-Kendall detects monotonic trend in time series annual data as well as its direction while the Sen's test quantifies the size of the trend [1]. The time series data need not conform to any pattern. It is an excellent trend test technique [21 - 23]. Mann-Kendall test is applicable in the cases when the data values $x_{i}$ of the time series can be assumed to obey the model $x_{i}=f\left(t_{i}\right)+\varepsilon_{i}$ where $f\left(t_{i}\right)$ is continuous increasing or decreasing function of time and the residuals $\varepsilon_{i}$ can be assumed to be from the same distribution with zero mean. The result of Mann-Kendall test is given in terms of $S$ statisticsif the data size is not above 9 otherwise it comes in terms of $Z$ statistics. In this study, the data size is larger than 9, therefore $Z$ statistics will be employed. A positive $Z$ statistics indicates an increasing trend while a negative mean a decreasing trend. The null hypothesis is rejected if $|Z|>Z_{(1-\alpha) / 2}$ where $Z_{(1-\alpha) / 2}$ is obtained from the normal cumulative distribution and $\alpha$ is the level of significance. The levels of significance $(\alpha)$ that can be tested are 0.001, 0.01, 0.05 and 0.1 . According to [18], the linear model of $f\left(t_{i}\right)$ is represented by $f\left(t_{i}\right)=Q t+B$, where $Q$ is the magnitude of the slope of the trend resulting from Sen's test and constant $B$ is the value of the first set of observation in the series. The period under review were divided into eleven decades ranging from 1901 to 1910 as the first decade, 1911 to 1920 as second decade and finally $2001-2010$ as the eleven decade [13]. The mean of rainfall rate for each month was determined and these were plotted against the months of the year to reveal variation of rainfall for the decades. The result is presented graphically in Figure 5. SI is defined as the sum of the absolute deviation of mean monthly rainfall from the overall monthly mean divided by the mean annual rainfall [24]. SI is another means of characterizing the fluctuation in rainfall by showing the different rainfall regime. According to [25, 26] SI is given by

$$
S I=\frac{1}{R} \sum_{n=1}^{12}\left|X_{n}-\frac{R}{12}\right|
$$

where $R$ is the annual rainfall and $X_{n}$ is the rainfall of month $n$. Theoretically, the $S I$ varies from zero (if all the months have equal rainfall) to 1.83 (if all the rainfall occurs in one month). The categories of rainfall regimes and their limits are presented in Table 1. The annual seasonality indexes for all the years were determined.

Table 1: Rainfall regime and equivalent seasonality index

\begin{tabular}{ll}
\hline SI & Rainfall Regime \\
\hline$<0.19$ & $\begin{array}{l}\text { Rainfall spread throughout the year } \\
\text { Rainfall spread throughout the year, } \\
\text { but with a definite wetter season }\end{array}$ \\
$0.20-0.39-0.59$ & $\begin{array}{l}\text { Rather seasonal with a short drier } \\
\text { season }\end{array}$ \\
$0.60-0.79$ & Seasonal \\
$0.80-0.99$ & $\begin{array}{l}\text { Markedly seasonal with a long dry } \\
\text { season }\end{array}$ \\
$1.00-1.19$ & $\begin{array}{l}\text { Most rainfall in less than 3 months } \\
\text { Extremely seasonality, with almost all } \\
\text { rainfall in 1 or 2 months }\end{array}$ \\
\hline & Sourced from [27]
\end{tabular}


The long-term mean of SI was computed using [27]

$$
S I_{m}=\frac{\frac{1}{R} \sum_{n=1}^{12}\left|X_{n}-\frac{R}{12}\right|}{N}
$$

where $N$ is the number of years covered by the data. The long-term mean is a concise summary of the SI over the study period.

\section{RESULTS AND DISCUSSION}

The mean and SD are presented in Figure 1. The amount of rainfall presented in terms of monthly mean increases from a lowest value of $3.722 \mathrm{~mm}$ in January to the highest value of 227.497 in August and thereafter reduces again. The measure of dispersion from this mean represented by the $\mathrm{SD}$ also fluctuates as the mean. The lowest and the highest SD occur in January and August respectively. The mean rainfall and SD varied across the months of the years.

The $Z$ statistics is positive which implies upward trend for all the month of the years at 0.1 level of significance. The null hypothesis of no trend was rejected for three consecutive months: November, December and January because $|Z|>Z_{(1-\alpha) / 2}$, where $Z_{(1-\alpha) / 2}=0.1736$. The $Q$ statistics which represents the slope of the trend is also positive for all the months but the values for November, December and January are small compared to the other months of the year. The $\mathrm{Z}$ and $\mathrm{Q}$ statistics are graphically presented in Figure 2. The amounts of rainfall fluctuate across the months of the years.

The years and months in which maximum and minimum amounts of rainfall occur corroborate variations in rainfall activities in Nigeria. As shown in Figure 3, these variations across the months followed the same pattern as the mean values. The most and least maximums occurred in July and January while the most and least minimums came up in August and January respectively. However, the months and years in which these took placed followed a zigzag pattern as presented in Figures 3. The amount of rainfall varies across the years. This indicates that rainfall variation is not only across the months but also across the years.

SI varied across the years with minimum of 0.706 and maximum of 0.924 in 1991 and 1983 respectively. The long-term mean SI for the period assessed stood at 0.779 for the period being study. Figure 4 reveals the rainfall regime in Nigeria varied between seasonal and markedly seasonal with long period of drier season. About three to six months of the year may be wet while the rest dry. The number of months of wet season may sometimes be fewer than those of dry season. A plot of SI against year reveals that rainfall usually concentrates within few months of each year. This connotes fluctuations in rainfall amount across both months and years. A lot of water is wasted during the few wet months as runoff and flooding. The excess water can be harvested, stored in places like dams and treated for use during the long dry months. This will reduce incidence of flooding and associated disasters. It will also ensure food production throughout the months of the year. Figure 5 presents the decadal means across the months of the year and it shows a rise in magnitude of rainfall in the second month until it reaches maximum in August and then nosedive in December. The second and six decades have their maximums in July and September respectively. The minimum and maximum decadal means of 2.75 and 242.28 occurred in January of the tenth decade and August of the seventh decade respectively.

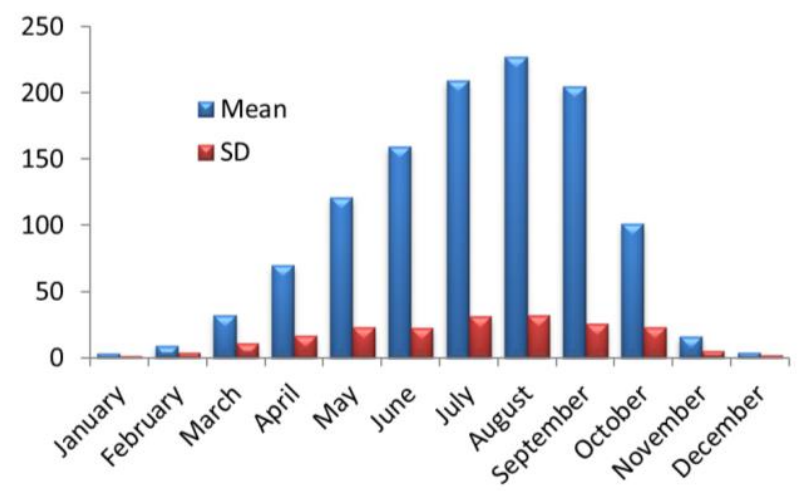

Fig. 1: Plot of Mean and Standard Deviation for each Month

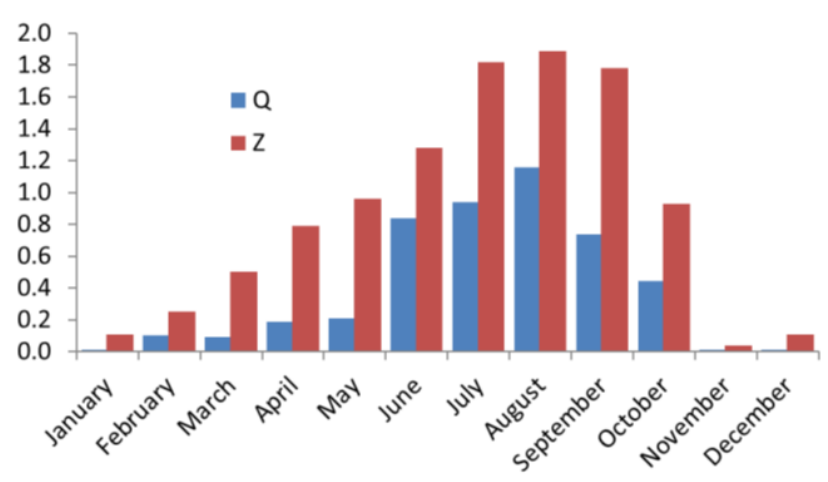

Fig. 2: Mann-Kendall (Z) and Sen's (Q) Statistics for each Month



Fig. 3: Plot of Maximum and Minimum Values with Year and Month of Occurrence.

Vol. 37, No.2, April 2018 


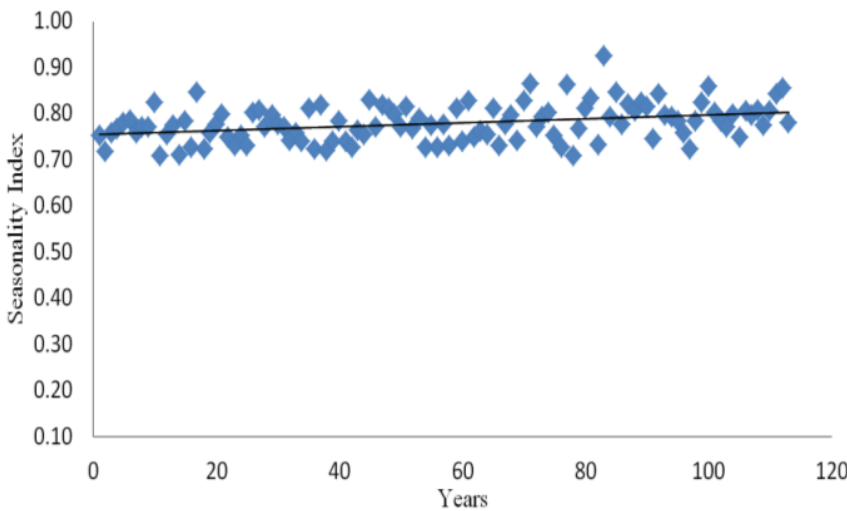

Figure 4: A plot of annual seasonality index against year

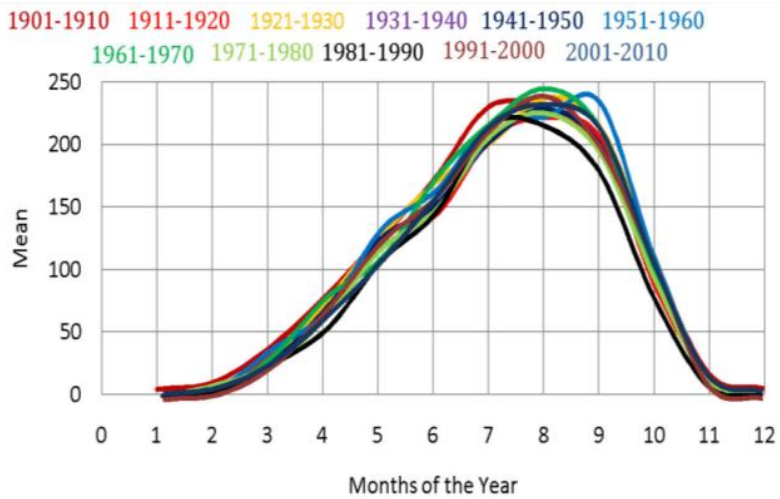

Figure 5: Decadal Mean Rainfall across Months of the Year

\section{CONCLUSION}

The fluctuation in amount of rainfall in different months was assessed using MAKESENS $®$ statistics. The means, $\mathrm{SD}, \mathrm{Z}$ and $\mathrm{Q}$ statistics, maximum and minimum amounts of rainfall all showed higher values around July and August and lower values around December and January. The fluctuations in years in which the maximums amounts of rainfall occurred followed a zigzag pattern. The same holds for minimums amounts of rainfall. The maximum, minimum and long-term mean seasonality indices are $0.924,0.706$ and 0.779 respectively, which indicate seasonal and markedly seasonal with a long dry season. The rainfall regime in Nigeria varied between seasonal and markedly seasonal with long period of drier season. The wet months do not have equal amount of rainfall and neither through the years.

\section{ACKNOWLEDGEMENT}

I appreciate the World Bank Climate Change Knowledge team, for making rainfall data utilized in this study available via their portal archives.

\section{REFERENCES}

[1] Ismail, A and Oke, I. A. "Trend analysis of precipitation in Birnin Kebbi, Nigeria" International Research Journal of Agricultural Science and Soil Science, Vol. 2 (7), pp 286-297, 2012.

[2] Olabode, E. A. and Adeleke, A. D."Statistical Analysis of Rainfall Trend In Akure, Ondo State, Nigeria" Analele Universitătii din Oradea, Seria Geografie, pp 114-121, 2017.

[3] Okorie, F. C. "Analysis of 30 years rainfall variability in Imo State of southeastern Nigeria" Hydrological Sciences and Water Security: Past, Present and Future pp 131 -132, 2015.

[4] Michaelides, S. C., Tymvios, F. S. and Michaelidou, T. "Spatial and Temporal Characteristics of the Annual Rainfall Frequency Distribution in Cyprus", Atmos. Res., 94, pp 606-615, 2009.

[5] Kumbuyo C. P., Yasuda H., Kitamura Y. and Shimizu K. "Fluctuation of Rainfall Time Series in Malawi: An Analysis of Selected Areas", GEOFIZIKA, 31, pp 13 - 28, 2014

[6] Guhathakurta P. and Saji E. "Detecting Changes in Rainfall Pattern and Seasonality Index vis a vis Increasing Water Scarcity in Maharashtra", Journal of Earth System Science,122 (3), pp. 639 649,2014

[7] Abolade O., Muili A. B. and Ikotun S. A. "Impacts of flood disaster in Agege Local Government Area Lagos, Nigeria", International Journal of Development and Sustainability, 2 (4),pp 2354 2367, 2013.

[8] Nemine E. L. "Flood Disasters in Nigeria: Farmers and Governments' Mitigation Efforts", Journal of Biology, Agriculture and Healthcare, 5 (14), pp 150 - 154, 2015.

[9] Murdock, T. Q., Fraser J. and Pearce C. "Preliminary Analysis of Climate Variability and Change in the Canadian Columbia River Basin: Focus on Water Resources", Pacific Climate Impacts Consortium, University of Victoria, Victoria BC, 57, pp 245, 2007.

[10] National Oceanic and Atmospheric Administration, "Observing Climate Variability and Change",. Retrieved from: http://www.oar.noaa. gov/climate/t_observing. html. (Accessed date: September 23, 2017), 2007.

[11] Zaman R., Malaker P. K., Murad K. F. I. and Sadat M. A."Trend Analysis of Changing Temperature to Global Warming", Journal of Biodiversity and Environment, 3 (2), pp 32 - 38, 2013.

[12] Bates, B.C., Kundzewicz, Z. W., Wu S. and Palutikof, J. P. "Climate Change and Water. Technical Paper of the Intergovernmental Panel on Climate 
Change", IPCC Secretariat, Geneva, Retrieved from:

http://www.ipcc.ch/meetings/session28/doc13.p df. (Accessed date: September 15, 2017) , 2008.

[13] Abaje I. B., Ishaya S. and Usman S. U. "An Analysis of Rainfall Trends in Kafanchan, Kaduna State, Nigeria". Research Journal of Environmental and Earth Sciences 2(2), pp 89-96, 2010.

[14] Coscarelli, R. and Caloiero, T. "Analysis of daily and monthly rainfall concentration in Southern Italy - Calabria region", Journal of Hydrology, 416, pp145-156, 2012.

[15] Egor, A. O., Osang, J. E., Uquetan, U. I. , Emeruwa, C. and Agbor, M. E. "Inter-Annual Variability of Rainfall In ome States Of Southern Nigeria", International Journal of Scientific \& Technology Research Vol. 4, Issue 10, pp 1324 - 154, 2015.

[16] Benson, C. and Clay E. J. "The impact of drought on sub-Saharan African economies: A preliminary examination", World Bank Publ., 1, WTP401, 1998.

[17] Cooper, P. J. M., Dimes, J. K., Rao, P. C., Shapiro B., Shiferaw, B. and Twomlow, S. "Coping better with current climatic variability in the rain-fed farming systems of sub-Saharan Africa: An essential first step in adapting to future climate change", Agriculture Ecosystem and Environment, 126 (12), pp 24-35, 2008.

[18] Maidment, R. I., Grimes, D. I. F., Allan, R. P., Greatrex, H., Rojas, 0. and Leo, O. "Evaluation of satellite-based and model re-analysis rainfall estimates for Uganda", Meteorological Application, 20(3) pp 308-317, 2011.

[19] Yosef B. A. and Asmamaw, D. K. "Rainwater Harvesting: Option for Dry Land Agriculture in Arid and Semi-Arid Ethiopia", International
Journal of Water Resources and Environmental Engineering. 7 (2) 17 - 26, 2015.

[20] Zeng, R., Cai, X., Ringler, C. and Zhu, T. "Hydropower versus Irrigation-An Analysis of Global Patterns", Environmental Research Letters. 12, , pp $5-8,2017$.

[21] Salmi, T., Määttä, A., Anttila, P., Ruoho-Airola, T., Amnell, T. and Laitos, I. "Detecting Trends of Annual Values of Atmospheric Pollutants by the Mann-Kendall Test and Sen's Slope Estimates -The Excel Template Application Makesens, Meteorologiska Institutet, Finnish Meteorological Institute, Helsinki, 2002.

[22] Tabari, H., Marofi, S. and Ahmadi, M. "Longterm variations of water quality parameters in the Maroon River, Iran", Environmental Monitoring and Assessment, 177, pp 273-287, 2011.

[23] Adenodi R. A., Akinluyi F. O., Adegboyega S. A., Ojo O. L. and Akinyemi P. "Trend Analysis of Mean Global Temperature: Implications on Bio-Climatic Conditions and the Need for Mitigation", Journal of the Nigerian Association of Mathematical Physics, 34, pp. 133 - 140, 2016

[24] Livada I. and Asimakopoulos D. N. "Individual Seasonality Index of Rainfall Regimes in Greece", Climate Research, 28, pp 155 -161, 2005.

[25] Walsh R. P. D. and Lawler D. M. "Rainfall Seasonality Description, Spatial Patterns and Change through Time", Weather, 36, pp 201-208, 1981.

[26] Kanellopoulou, E. A. "Spatial distribution of rainfall seasonality in Greece", Weather, 57 (6), , pp $215-219,2002$.

[27] Patil M. K. "Change in Seasonality Index of Rainfall in Sangli District", Indian Streams Research Journal Vol. 5 (1), pp 1 - 7, 2015. 